\title{
Influence of Government Support on Proactive Environmental Strategies in Family Firms
}

\author{
Sonia Benito-Hernández ${ }^{1, *}$ (D) Cristina López-Cózar-Navarro ${ }^{1}$ and Tiziana Priede-Bergamini ${ }^{2}$ \\ 1 Department of Agrarian Economics, Statistics and Business Management, Polytechnic University of Madrid, \\ 28040 Madrid, Spain; cristina.lopezcozar@upm.es \\ 2 Departament of Economics and Business, Universidad Europea de Madrid, 28670 Madrid, Spain; \\ tiziana.priede@universidadeuropeademadrid.es \\ * Correspondence: sonia.benito@upm.es
}

Citation: Benito-Hernández, S.; López-Cózar-Navarro, C.;

Priede-Bergamini, T. Influence of Government Support on Proactive Environmental Strategies in Family Firms. Sustainability 2021, 13, 13973. https://doi.org/10.3390/su132413973

Academic Editor: David K. Ding

Received: 13 October 2021

Accepted: 13 December 2021

Published: 17 December 2021

Publisher's Note: MDPI stays neutral with regard to jurisdictional claims in published maps and institutional affiliations.

Copyright: (c) 2021 by the authors. Licensee MDPI, Basel, Switzerland. This article is an open access article distributed under the terms and conditions of the Creative Commons Attribution (CC BY) license (https:// creativecommons.org/licenses/by/ $4.0 /)$.

\begin{abstract}
Scholars have dedicated significant efforts to understanding the factors that influence the environmental strategy of a firm, in order to mitigate the negative impacts on the ecosystem. Learning more about the factors that encourage environmental behavior allows managers and policy makers to improve action and advance correctly in this direction. Despite this academic interest, the literature regarding family business has undertaken limited attention over the issue. Hence, our paper aims to advance in this line of research, by empirically examining the relationship between government support in family firms and their investment in environmental protection. Specifically, we intend to analyze whether the family nature, and the government financial support, influence their environmental strategy. The empirical analysis is developed with a sample of 1802 manufacturing firms in Spain, using a binary logistic regression to evaluate the existence of dependency relationships between the analyzed variables. The results show this dependency, confirming family nature and government support as significant factors for a proactive environmental strategy, funding the idea that family character positively affects environmental performance in line with the socio-emotional wealth approach, and these differences are greater if the company operates mainly in a local area. Likewise, family firms that receive state direct and indirect funding, invest more in environmental issues to mitigate negative external impacts. The practical implications of the results obtained are especially useful for managers of family businesses as well as for central governments and local institutions as a matter of reflection. To reduce administrative processes and costs for family firms in terms of direct and indirect support is of great importance, as an inadequate process may become a barrier to develop environmental strategies.
\end{abstract}

Keywords: family firms; proactive environmental strategies (PES); public policies; government support; socio emotional wealth (SEW)

\section{Introduction}

The European Commission, in its publication of 2011 [1], A renewed EU strategy 2011-14 for Corporate Social Responsibility, updated the concept of corporate social responsibility (CSR) as "the responsibility of companies for their impacts on society". The Commission's renewed strategy argues that to assume this responsibility, companies must have a process in place to integrate into their business operations and in close collaboration with stakeholders, social, environmental, ethical, human rights and consumer's concerns.

Firms may develop CSR - in which the environmental strategy of the firm is includedalong a continuum, extending from a reactive to a proactive approach. Therefore, the degree to which every firm develops CSR strategies will vary widely among them, depending on the decisions adopted by the managers and the firm's orientation $[2,3]$. Those adopting a proactive CSR attitude reach further regulatory requirements and engage voluntarily in active social responsibility issues as a competitive priority [4]. 
Today, the situation of the Earth has aroused widespread concern about the overall impact of industrial and commercial activities on the natural environment, and increasingly social pressures demand politicians, public administrations, and private companies to commit on these important issues, and thus contribute to sustainable development. The interest in the proactive environmental strategy (PES) has itself fueled a growing body of research and publications in recent years. PES are intangible managerial innovations policies, practices and routines adopted by the organization towards improving the protection of the natural environment and to implement actions to reduce waste, prevent pollution, or minimize water and energy consumption [5-8]. There is a great academic interest on PES, although the literature regarding family business (FB) is less extensive [9].

FB present differences compared with other companies, arising precisely from the influence of the family on the strategy statements: mission, vision, values, goals, and objectives of the company [10-12]. These differences must be also reflected in their attitude towards CSR policies $[13,14]$. Furthermore, CSR is a broad concept with several dimensions, thus the behavior of a company can be different across several aspects, being responsible in some matters and not responsible in others [15-17]. Thus, we believe that it is timely and relevant to deepen in the analysis of CSR in family-controlled firms, considering its development and relevance in most economies around the world.

The present paper addresses this line of research, unlike previous literature, focusing mainly on the development of PES on FBs. Although many articles approach CSR on FBs, few studies have relied specifically on environmental issues [18-23]. Besides the gap in the literature of existing studies on the causal drivers of FB's responsible behavior, we find it interesting to develop this analysis, because it allows managers and policy makers to determine the relative effectiveness of the different mechanisms and measures implemented to promote sustainability. According to the UN [24] definition, environmental sustainability consists of ensuring that future generations have sufficient resources to have the same quality of life, or better, than present ones. It focuses on the ecological footprint of human activity and how to reduce it to improve our life on the planet.

Our research will contribute to filling this gap by examining the influence of public support over environmental protection actions in FBs, to induce sustainable and responsible practices. Understanding FB's decisions over these issues is very important due to their significant economic impact; indeed, FBs are highly influential organizations with the potential to assist governments - and society as a whole — to address the environmental challenge that the world is facing today [25,26]. As Sharma and Sharma [9] point out, the impact of FB's engagement with environmental matters on state and civil society has been clearly undervalued by researchers. Therefore, we take the challenge to describe how those family firms who benefit from public assistance, invest or not to a greater extent on environmental protection; in order to improve knowledge for managers and policy makers to advance correctly in the promotion of sustainable FB's practices.

Consequently, based on the literature, our three research questions arise: (1) Does the government support affect FB's environmental concern and expenses in PES? (2) Are there significant differences among family and non-family firms over PES? (3) Is there a positive relationship between state or local, direct and indirect funding, and FB's environmental concern? To achieve our objectives, in the next section, we provide the main arguments of the literature presenting our hypotheses and their rationale. The data analysis and methodology explain our approaches to data collection and measurement. Finally, we present the results, discussion, conclusions, practical implications, limitations and directions for further research. The study focuses on Spain because the business environment is characterized by its small size and youth; therefore, the problems of access to financing resources are very typical. Likewise, the state organizational structure, divided by autonomous communities with an important part of self-financing, makes it interesting to analyze the applicability of the different policies carried out both locally and nationally in order to observe which ones have the greatest impact on business actions related to environmental protection. Furthermore, the interest of the Spanish government 
on environmental issues has widely increased in the past few years, supported by the recent publication of the Law 7/2021, on climate change and energy transition, adapting to the European requirements.

\section{Literature Review}

Different levels and types of responsiveness will vary considerably across organizations $[17,27]$; indeed, an aspect of PES is the leadership role played by those at the top-level management $[3,28]$. In FBs, the fact that ownership, management, and family interact as three different coexisting subsystems [29], affects many business' decisions. Indeed, each of these groups has its own aspirations and interests, involving multiple and complex relationships among them. These relations are often the cause of differences with their non-family counterparts, - in which ownership and management are the two main interacting groups - in terms of goals, operations, culture, organizational structures and strategic behavior [10,30-32]. Indeed, Gómez-Mejía et al. [11] argues that socioemotional wealth or affective endowment of family owners explain many of these differences specially in organizational choices regarding firm strategies, management processes, or stakeholder relations among others.

One specific theoretical framework that must be considered when addressing CSR policies within the family businesses, which closely reflects the nature of these firms, is the Socioemotional Wealth Theory (SEW) [33-35]. The SEW theory is based on conserving and protecting the social and emotional family heritage for future generations, such as the family name, culture and firm reputation. The preservation of SEW involves maintaining emotional ties with the family business in order to conserve intact the legacy for future generations. According to the SEW model, family businesses focus primarily on preserving their SEW. Thus, the gains or losses in such wealth will be the basis for making important strategic and political decisions.

It seems logical to think that the FB will adopt a long-term approach in its main management decisions, so building a solid and lasting relationship with the stakeholders and with the community to which it belongs is consolidated as one of the preferred options, in line with the close identification of the family with the firm as a dimension of SEW theory [12]. Indeed, family participation in the company generates a unique identity intimately linked to the organization. Thus, internal and external stakeholders, will perceive the organization as an extension of the family, a fact that obviously will have important consequences on their strategic decisions and policies.

As reported by Berrone et al. [12], FBs show higher levels of CSR and community citizenship, due to the strong identification with the firm's name and because public disapproval could be emotionally distressing for family members. In this line, sustainability practices will be adopted at a social and environmental level in order to build a good reputation and maintain SEW. Nevertheless, and also in the same line, the fact that FBs are focused on preserving SEW may lead them in the opposite direction towards CSR; that is, family managers may be less willing to invest in CSR activities, since these options are not related to obtaining benefits in the short term [16,36]. In short, FBs frame their decisionmaking process by evaluating how actions will affect the socio-emotional endowment. If this endowment is threatened, FBs can make decisions that are not based on economic logic, even putting the business at risk if necessary, to preserve that endowment $[11,12]$.

As shown by the literature, the FB's management differs from non-family firms affecting their global CSR approach; consequently, how these companies respond to the specific environmental commitments by identifying, implementing and managing its responsibilities over these issues is also expected to be different. The way in which FBs react to environmental responsibility decisions and how they are affected by public policies and support is of great relevance. 


\subsection{Family Nature and PES}

Regarding family character and PES, based on the intrinsic differences between family and non-family businesses, the literature shows some discrepancy over the issue. Craig and Dibrell [18], with a sample 396 across all industries in the western United States, show interesting differences on natural environmental policies between family and non-family firms. They find that non-family firms reported higher and more significant interest on natural environmental policy than FBs. However, these non-family firms were not able to exploit or translate this stronger emphasis on natural environmental policy into either greater firm innovation or firm financial performance (strategic responsiveness), while FBs demonstrated a greater ability to do it. Thus, PES was found to be more positively associated with innovation and performance in FBs. These results are in line with the idea that the management of the FB has a positive influence when it comes to strengthening the spirit in the long term.

Berrone et al. [19] compared the environmental performance between family and non-family with a sample of 194 firms in polluting industries, finding that the family character affects positively the environmental performance, showing better results than their non-family rivals. These differences were greater if the firm operated mainly in a local area. The results confirm that a strong FB presence and significant roots in the local community are positive factors in PES in order to enhance the family's image and protect their SEW. Indeed, Berrone et al. [12] point out that as the family's participation in the control of the company increases in relation to other non-family shareholders, it will apply environmentally friendly policies with fewer restrictions, even if these are riskier strategies.

Meanwhile, Sharma and Sharma [9] analyze the variability of the family engagement in the three FB subsystems: ownership, management and governance, since these may change significantly over time in the same FB, as well as in different family firms. Based on the theory of planned behavior, these authors develop a conceptual framework of PES in FB. They suggest that family-owned and operated firms are more likely to have positive intentions to pursue PES than other family firms and non-family firms. They also demonstrate that lower levels of conflicts will improve these organizational capabilities.

More recently, Samara et al. [26], using qualitative comparative analysis, conclude that different levels of family involvement in ownership and management, affect the family firm environmental social performance. Given these circumstances, it seems that family management engagement is an important driver for PES. Dekker and Hasso [20], using a sample of 1452 Australian SMEs, find a lower environmental performance interest than nonfamily firms, but not in all cases, because those FBs that were more engaged with the local community moderated the negative effect, displaying higher attention to environmental performance. Consequently, if FBs have a strong social embeddedness, they are more interested in achieving socio-emotional wealth related to environmental performance.

Given that, in many cases, PES included in the CSR strategy of the firm, the literature also shows a wider point of view over the issue. Block and Wagner [15], in a study analyzing different CSR dimensions using a sample of large US firms, show that the influence of family character may change and be positive or negative depending on the different CSR dimensions. Accordingly, they find that it has a negative impact with community-related CSR performance, and a positive impact with other aspects of CSR, such as diversity, employee, environment, and product-related issues, thus highlighting the negative and positive aspects of the previous literature. Cruz et al. [37] discuss the possible positive effects of family ownership on social activities aimed at external stakeholders-such as the environment-considering the literature support validating that family control induces CSR activities; nevertheless, they find that FBs are not significantly different from nonfamily firms, when it comes to external stakeholders, because they both engage in a comparable sense, at least in the European context in which the research was conducted. Campopiano and De Massis [38] show that FBs release more information than non-family firms on environmental and green issues as well as about philanthropy, maybe due to their higher concern for environmental issues and their important role when linking 
institutional pressures and firm response, on the road to a constant search for legitimacy in its institutional context. In the same line, but based in a theoretical perspective, Le Breton-Miller et al. [39] identified diverse conceptual elements to approach the positive and negative family firms' characteristics for sustainability implications, accepting that not all FBs develop as good corporate citizens. They propose a wide definition of sustainability (resembling CSR) based on those business practices that pursue the fulfillment of all stakeholder's interests with a long-term view, to improve the health of the firm, the environment, and the society at large. Among the positive factors that may explain in which conditions FBs are more likely to adopt sustainable practices, they consider family values and educational backgrounds, governance arrangements, organizational factors, and environmental forces.

Meanwhile, Huang et al. [40] examine how family influence affects firms' adoption of eco-innovation (considering eco-innovation or ecological innovation as the development of products and processes that contribute to sustainable development, applying knowledge and commercial strategies to generate ecological improvements directly and indirectly). They find that both family ownership and family control significantly and negatively affects firms' adoption of green production innovation. Memili et al. [41], with a sample of 327 FBs in the hospitality industry, find family character to be negatively and significantly related to the adoption of sustainability practices, again approaching the wider concept of CSR, including corporate governance, workplace practices, environmental protection, community engagement, and relationships with stakeholders. However, they also point that this negative relationship dims with high levels of long-term orientation. Furthermore, Doluca et al. [21] find that German FBs implement sustainability related measures slower than non-family firms but show less instability. In the long term, they report convergence finding that both types of firms look to accomplish similar results in terms of environmental activities, innovations and performance. Dangelico et al. [22], using a multiple case study methodology with a sample of small firms, analyze the differences between family and nonfamily firms in terms of eco-innovations, finding no significant differences in the innovation process or the results obtained; however, they do find differences in the motivations, pressures, and vision that the companies have about this type of innovation. Finally, Dou et al. [23] show that the positive effect of family character over environmental practices is affected by long-term orientation, and this influence is more significant the higher the family's commitment is in the company.

In view of the information presented and given the ambiguity of the results, following Craig and Dibrell [18] and Berrone et al. [19], we believe that FBs may be especially interested in protecting the natural environment and future generation's well-being due to the identification of the family with the firm. Consequently, we expect a different behavior towards PES among family and no-family firms. The following hypothesis is presented:

Hypothesis $\mathbf{1}\left(\mathbf{H}_{\mathbf{1}}\right)$ : The family nature of the business has a significant effect on the environmental protection actions.

\subsection{Government Support towards PES}

\subsubsection{Direct and Indirect Public Support}

Since the late 1980s, the questions of why and how corporations should incorporate environmental issues into strategic decision making has been of high interest for managers, policy makers and scholars. Environmental protection activities are those whose main purpose is the prevention, reduction and elimination of pollution and other forms of environmental degradation. They include, but are not limited to: the prevention, reduction or treatment of waste and wastewater; the prevention, reduction or elimination of emissions into the atmosphere; treatment of contaminated soil and groundwater; the prevention or reduction of noise and vibration levels; the protection of biodiversity and landscapes, including their ecological functions; monitoring the quality of the natural environment (air, water, soil and groundwater); research and development of environmental protection; and, 
the activities of the general administration, training and education aimed at the protection of the environment.

Authors such as Bansal and Roth [6] emphasize the importance of examining why some firms embrace ecologically responsible initiatives, as well as the main factors that influence firm's environmental commitment. With this evidence, both managers and policy makers, improve information over the issue and are better able to determine the impact of the different mechanisms and measures implemented to promote business' sustainability and thus, make better decisions. In this same line, Bansal [42] argues that only through such research is it possible to develop public and private policies that really influence corporate sustainable development.

Among the main factors influencing corporate behavior, literature shows the importance of funding availability for environmental practices [43-45]. Indeed, Ociepa-Kubicka and Pachura [46] point lack of financial resources-either external or internal-among the main barriers limiting eco-innovation. In the same line, Scarpellini et al. [47] through an empirical analysis show the close relationship among financial resources and eco-innovation developed by the firm.

Thus, several authors conclude that public financial support have a clear positive influence on environmental investment, therefore confirming the relevant role of the state in promoting the firm's corporate responsibility and eco-innovation. Horbach [48] show a significant positive influence of public grants on environmental innovations; meanwhile, De Marchi [49] find public financing as significant and positive when explaining a firm's innovative environmental performance. Likewise, Hoogendoorn et al. [50] find that SMEs that receive financial support are more likely to be involved in environmental practices, although these authors do not distinguish among public or private funding. Triguero et al. [45] also show that public support positively influences the adoption of eco-innovation. Cecere et al. [51] points out that public financing is an important driver for eco-innovations, especially for SMEs; although, these funds must complement own investments, to avoid diversions to cover other company needs.

Consequently, there seems to be agreement over the fact that those companies that receive public resources encourage sustainable practices; nevertheless, these granting involves a bureaucratic process of requesting and awarding, which complicates its access. Indeed, not all companies receive the aid, and in many cases, it is not assigned to those in greatest need. In this sense, Blanes and Busom [52] explain that the effectiveness of direct support depends on the process itself, since the selection may not be correct, or the fund may not reach the target audience. Fort the specific case of eco-innovation, Mazzanti and Zoboli [53] find that few firms really take advantage of environmental grants, maybe due to the high administrative and/or informative costs.

Thus, although it is true that obtaining public aid is a factor that clearly enhance the effort of the company when adopting a proactive attitude towards environmental concern, it is also true that the administrative process related to this support turn out to be a limitation. In this sense, Ociepa-Kubicka and Pachura [46] indicate that an inadequate access to existing public support or fiscal incentives, is a barrier to eco-innovations.

In this article, we aim to increase knowledge about the relationship between the public support, and its materialization in a proactive and responsible business attitude, measured through the expenses on environmental protection; as well as delving further addressing the origin and the type of the support, in order to make better decisions to promote business' sustainability. Accordingly, the following hypothesis are presented:

Hypothesis 2a $\left(\mathbf{H}_{\mathbf{2 a}}\right)$ : There is a significant relationship between receiving local public funding and environmental protection expenses.

Hypothesis $\mathbf{2 b}\left(\mathbf{H}_{\mathbf{2}} \mathbf{b}\right)$ : There is a significant relationship between receiving state or other public funding and environmental protection expenses. 
Hypothesis $\mathbf{2 c}\left(\mathbf{H}_{2 c}\right)$ : There is a significant relationship between tax deductions benefits and environmental protection expenses.

\subsubsection{Direct and Indirect Government Support and Family Firms}

As previously commented, and based on the SEW theory, the differences between family and non-family firms are also reflected in their attitude towards CSR policies [16,36]. In this sense, there are some FB's characteristics that may be considered as strengths when adopting responsible behavior, but at the same time, other elements may act as weaknesses. Regarding the positive aspects, family involvement in management decisions contributes to transfer the principles and values of the family to the business: cooperation, emotional bonding, unity, as a sense of responsibility and loyalty to the group [17]. Similarly, family managers are more likely to take a long-term view of the value tradition, the corporate reputation, process and product quality and company success, over financial performance and returns. In addition, FB tend to engage with the stakeholders in a unique way, since they often have a strong presence in the local community and show very high concern about their problems and worries, e.g., [28,54,55]. On the negative side, it is common in FB to prioritize the interests of family members beyond those of the company or other stakeholders, such as the typical nepotism or the use of financial resources to meet the family objectives over the company's needs; thereby creating distress and conflicts inside and outside the family and the business $[31,39]$.

Our research will contribute, in particular, to improve knowledge over the drivers that boost the family firm's PES. Specifically, by examining the influence of different types of government support over their environmental protection actions. In general terms, literature on FB has studied the relationship among government support and innovation investments. Lopez-Fernandez et al. [56] study the factors that influence family SME's innovation decisions, highlighting the lack of financial resources as one of the main limitations; thus, public involvement offering financial support, good condition loans or fiscal incentives may contribute to solve the problem, encouraging R\&D's expenditures. Schäfer et al. [57] find that internal financial sources are the most important to develop innovation, either for family and non-family firms; nevertheless, public grants are of great importance for non-family firms, and to a lesser extent for FBs. Carney et al. [58], analyzing lean innovation and its application to FBs patenting strategies, find a negative but significant relationship between government subsidies and R\&D investment. Manzaneque et al. [59] consider that receiving government funding for innovation may affect its results, and study if factors such as family management and financial availability, could affect the reactions to performance pressures.

Regarding responsibility issues, Canavati [60], through a meta-analysis of 98 researches from 27 countries, prove that the relationship between FB and corporate social performance is positive for private family firms, but is negative for public family firms. Based on these results, the author suggests a government support via tax policies for family firms to incentivize them to continue private (e.g., reducing taxes or improving tax benefits deductions) for family holdings, and increasing taxes for public family equity holdings. Meanwhile, Dou et al. [23] evidence that long-term orientation may facilitate the adoption of PES, and they recommend local governments and regional policy makers to use monetary or non-monetary incentives-such as tax incentives - to encourage firms to make long-term investments towards PES. In the same line, Martínez-Alonso et al. [61], examining how innovation influences sustainable economic performance, suggest that policymakers must protect family businesses and their long-term orientation, offering policies and programs that support and encourage innovation and the development of more efficient internal processes.

To the best of our knowledge, there is no empirical evidence to demonstrate the relationship between public support and PES in the case of the FB; thus, we present the following hypotheses also addressing the origin and the type of the support: 
Hypothesis $3 \mathbf{a}\left(\mathbf{H}_{3 \mathbf{a}}\right)$ : There is a significant relationship between receiving local public funding and the environmental protection expenses in family firms.

Hypothesis $3 \mathbf{b}\left(\mathbf{H}_{3 \mathbf{b}}\right)$ : There is a significant relationship between receiving state or other public funding and the environmental protection expenses in family firms.

Hypothesis 3c $\left(\mathbf{H}_{3 c}\right)$ : There is a significant relationship between tax deductions benefits and the environmental protection expenses in family firms.

In order to clarify the relationship between the hypotheses, a graphic diagram is presented in Figure 1.

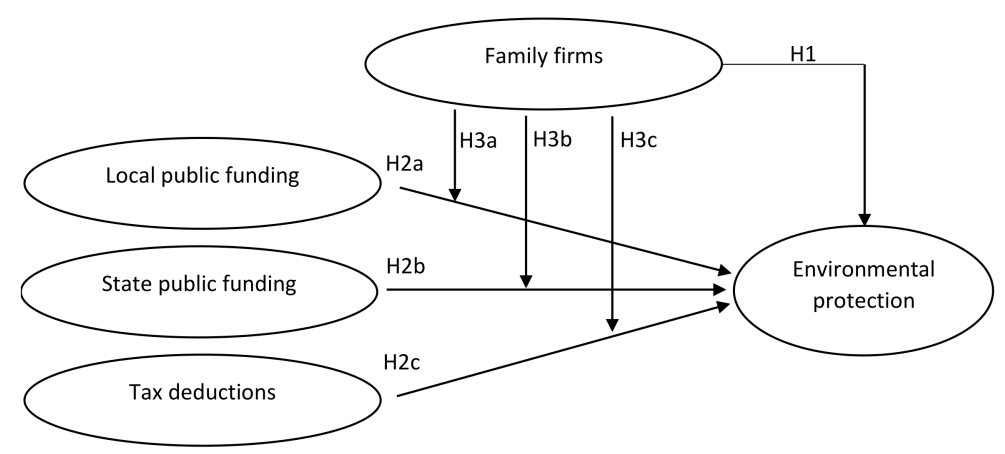

Figure 1. Hypothesis model. Source: author compiled.

\section{Data Analysis and Methodology}

\subsection{Sample and Data Collection}

This study uses information collected from the Survey on Business Strategies (SBS), which is a firm-level panel of data compiled by the Spanish Ministry of Science and Technology. The SBS is a statistical survey that gathers data from an annual business survey sent to a panel of Spanish manufacturing companies. In this range, companies are chosen by stratified samples grouped by activity sector and number of employees. This procedure, used to select firms participating in the survey, allowed us to estimate the distribution of any of the characteristics of the population of Spanish manufacturing firms with information available from our data set. This selection is conducted using the same proportion as in the original sample for technical details of the sample see [62]. It collects information on various aspects related to companies' strategic behavior and decision-making, as well as on their results and account balances. The SBS has been used in numerous FB papers, e.g., $[14,32,59,61]$. Table 1 shows the technical data of the study.

Table 1. Technical data or the study.

\begin{tabular}{cc}
\hline & Population \\
\hline Unit & Spanish manufacturing sector \\
Questionnaire design & SEPI Foundation \\
Population types & More than 100,000 elements. \\
Time period & Data from 2016 \\
\hline Type of sampling & Random stratified census according to activity sector and firm size. \\
Sample size & 1802 Spanish manufacturing firms \\
Sampling error (approx.) & $0.028(\mathrm{p}=\mathrm{q}=0.50)$ \\
Level of confidence & $95 \%(\mathrm{~K}=2$ sigma) \\
Data treatment & Statistical Solutions for Products and Services (SPSS). \\
\hline
\end{tabular}

Source: author-compiled data. 


\subsection{Variables and Measures}

\subsubsection{Dependent Variables}

This paper attempts to explain PES in FB. Therefore, following previous literature, we define PES as managerial innovations, policies and practices adopted by the firm towards improving the protection of the natural environment. These voluntary actions require the commitment of all members of the organization and an important mobilization of resources. One of the ways to check if the company develops this type of action is to observe if it dedicates part of its financial resources to these activities. For this reason, an objective indicator has been chosen to know whether the company makes these responsible actions through the expenses it dedicates to the protection of the environment.

The dependent variable was defined as dichotomous, indicating whether the company spends on not in environmental protection activities. We use this concept since we consider it to be relevant when indicating the proactive attitude of the organization towards the environment. It should be noted that, although it is not a long-term investment, many of the expenses in this direction may later be activated when the investment materializes. Thus, for example, hiring an independent professional to perform environmental consulting services is an expense of the year, but if the advice generates a process of innovation and change towards eco-investments, then that preliminary expense ends up included in the investment. The same occurs with R\&D expenses of any nature (salaries, supplies, etc.) that are activated at the end of the innovation process. In short, we consider that the dependent variable "expenses on environmental protection" represents a good indicator of the PES of the company. Cavaco and Crifo [63] and Earnhart [64] also use this variable to measure the improvement in environmental practices, since it is related to the firm's CSR policy as a measure of environmental performance. For FBs, Craig and Dibrell [17] also include this variable, although its measure is not dichotomous but categorical. They employ a five-indicator scale to measure the resource distribution decisions concerning the natural environmental policy of the firm; among the analyzed items, they include the "businesses need to spend more resources on environmental protection".

\subsubsection{Independent Variables}

As stated before, the aim of this paper is to study the influence of government support over environmental responsibility actions in FB. To reach our goal, we define five independent variables: family nature, local direct support, state direct support, other government aid, and indirect support such as tax deductions.

In the academic literature, a wide variety of indicators have been used to measure family nature; however, the majority agree on the requirement of family participation in ownership, active management, and governance [65]. Our survey includes a direct and dichotomous question (YES/NO) asking if a family group actively participate in the ownership and in the business management, which means that the decision-making power depends in the owner family. This variable has been measured this way in previous papers $[14,19,20,32,37,55]$.

Regarding public support, papers such as Horbach [48], De Marchi [49] and Hoogendoorn et al. [50], studied public funding sources as drivers for environmental innovation. For FBs, Lopez-Fernandez et al. [56] and Manzaneque et al. [59] use as well this variable, however not differentiating the origin of the support (local or central), neither the type of the action (direct or indirect), aspects that are both approached in this paper as a new contribution and challenge. The variables chosen as public financing, collect the total received by companies in different items: direct local grants, direct state grants, tax deductions and other types of minor public aid.

\subsubsection{Control Variables}

The paper considers control variables such as: size, income and company age. Previous literature has found a positive relationship between the company size and its environmental strategies. Craig and Dibrell [18] measure firm size through the number of employees 
and suggest that this variable may influence natural environmental initiatives in family firms. Cruz et al. [37] claim that larger firms seem to invest more in social activities. Finally, Neubaum et al. [66] also pointed out that most empirical studies demonstrate a positive relation between firm size and the success and implementation of PES.

Total incomes are of great importance specially for companies with difficulties to access other sources of financing or those who prefer auto-financing. Ociepa-Kubicka and Pachura [46] and Scarpellini et al. [47] highlight the importance of financial availability to develop eco-innovations. Berrone et al. [19] and Dekker and Hasso [20] use profitability as a dummy variable to control their models.

Finally, regarding company age, Martínez-Alonso et al. [61] introduce this variable measured as the number of years since the firm's incorporation. It is expected that younger firms show higher growth than older firms and, as well, higher environmental commitment. Other papers such as Cruz et al. [37], Dekker and Hasso [20] and López-González et al. [55] use age as a control variable. Table 2 describes the different variables. All variables in Table 2 are listed below.

Table 2. Model variables.

\begin{tabular}{|c|c|c|c|c|c|}
\hline $\begin{array}{l}\text { Type of } \\
\text { Variable }\end{array}$ & Study Variables & $\begin{array}{l}\text { Variable to } \\
\text { Analyze }\end{array}$ & Definition & Name & Values and Data Year \\
\hline Dependent & $\begin{array}{l}\text { Environmental } \\
\text { protection }\end{array}$ & $\begin{array}{l}\text { Expenses on } \\
\text { environmental } \\
\text { protection }\end{array}$ & $\begin{array}{l}\text { Categorical variable that } \\
\text { indicates whether the } \\
\text { company spends to control } \\
\text { of environmental pollution. }\end{array}$ & $\mathrm{EP}$ & $\begin{array}{c}1=\text { Expenditures on } \\
\text { environmental protection. } \\
0=\text { No expenditures on } \\
\text { environmental protection. }\end{array}$ \\
\hline \multirow{5}{*}{ Independent } & Family nature & Family business & $\begin{array}{l}\text { Indicates whether the } \\
\text { company has family } \\
\text { character or not. }\end{array}$ & $\mathrm{FB}$ & $\begin{array}{c}1 \text { = Family Business } \\
0=\text { Non-family business. }\end{array}$ \\
\hline & \multirow{4}{*}{$\begin{array}{l}\text { Government } \\
\text { support }\end{array}$} & $\begin{array}{l}\text { Local direct } \\
\text { financing }\end{array}$ & $\begin{array}{c}\text { Financial resources received } \\
\text { from the local } \\
\text { administration. }\end{array}$ & LF & Total local financing. \\
\hline & & $\begin{array}{l}\text { State direct } \\
\text { financing }\end{array}$ & $\begin{array}{c}\text { Financial resources received } \\
\text { from the central/state } \\
\text { administration }\end{array}$ & SF & Total state financing. \\
\hline & & $\begin{array}{l}\text { Other public } \\
\text { financing }\end{array}$ & Other public financing & OPF & $\begin{array}{l}\text { Total other public } \\
\text { financing }\end{array}$ \\
\hline & & $\begin{array}{l}\text { Indirect support. } \\
\text { Tax deductions }\end{array}$ & $\begin{array}{l}\text { Total value of the } \\
\text { deductions applied in } \\
\text { corporate tax. }\end{array}$ & TD & Total tax deductions. \\
\hline \multirow{3}{*}{ Control } & & Size & & SIZ & Number of employees \\
\hline & & Income & & INC & Total incomes \\
\hline & & Age & & AGE & $\begin{array}{l}\text { Number of years since } \\
\text { incorporation }\end{array}$ \\
\hline
\end{tabular}

Source: author-compiled data.

\subsection{Analysis Methodology}

Descriptive statistical techniques and correlations have previously been used. Subsequently, a statistical regression estimation based on a binary logistic model was used to evaluate the relationship between public support and PES in family firms. This type of statistical analysis is applied since the dependent variable is dichotomous, and the estimation of a model through an OLS regression analysis could produce bias, even heteroscedasticity. Thus, a symmetric distribution (standard or logistic) and a maximum-likelihood estimator, as in a binary logistic model, must be used.

Other related papers that have also researched the relation among family business and environmental management have also employed this methodology, e.g., Blanes and 
Busom [52] tested a multinomial logit model to study the impact of grants over R\&D. Dekker and Hasso [20] and López-Cózar-Navarro et al. [14] also use the logit model. Lopez-Fernandez et al. [56] proposes a theoretical model tested by the estimation of a binomial logistic regression; and Manzaneque et al. [59] employs a conditional logistic regression to estimate the parameters and test the hypotheses.

\subsection{Results and Discussion}

The results of the descriptive statistics and correlations are shown in Tables 3 and 4 . As revealed for the descriptive statistics, more than half of the sample firms (55.4\%) do spend on environmental protection (EP), while $44.6 \%$ don't. Regarding independent variables, $43.6 \%$ of the sample are family business. It is interesting to highlight the low level of funding received directly from local and state public entities in absolute terms. Not so, in the case of fiscal deductions, with an average amount of EUR 49,646.

As shown in the binary logistic regression results in Table 5, we can accept $\mathrm{H}_{1}$. We found a positive and significant relationship among family nature and environmental protection actions. The results support the SEW approach; indeed, companies would be more likely to implement CSR activities [35]. These results are in line with Sharma and Sharma [9] and Samara et al. [26]. Like the work published by Berrone et al. [19], our results fund the idea that family character positively affects environmental performance, showing better results than its non-family rivals, and these differences are greater if the company operates mainly in a local area. Smaller firms mostly operate in these areas, as shown in the conclusions drawn by previously cited literature. It is then demonstrated that family management commitment-especially latent in SMEs—is an important driver for PES. In line with Berrone et al. [12], in those FBs with a greater presence of the family in decision-making, and especially in SMEs, the family will be able to impose its will over other non-family owners and the company will be able to apply environmentally friendly policies with fewer restrictions, even if these are riskier options.

Regarding the relationship between public support and PES, since we have not found previous literature about government support, distinguishing among local-state and directindirect funding, as we develop in this paper, we cannot compare lines of results with other previous research. Nevertheless, we can compare our results with other similar papers, although not at our level of detail. Accordingly, our results show a positive relationship between companies that receive state public support and their expenses in environmental protection activities, thus we can accept $\mathrm{H}_{2 b}$, which is in line with previous general literature [45,48-51] pointing to public financing as an important driver for ecoinnovations. However, it is not possible to accept $\mathrm{H}_{2 \mathrm{a}}$, which focuses specifically on public local support, even though authors such as Dou and et al. [23] in their study for FB recommend that local governments and regional policy makers must employ monetary and non-monetary incentives to encourage companies towards PES. In our results, we have not found evidence in this direction; rather, that the state or central governments are those facilitating these actions.

Regarding $\mathrm{H}_{2 c}$, we cannot accept this hypothesis either. Consequently, our paper is closer to that of Mazzanti and Zoboli [53], who point out that the very limited number of companies that really exploit environmental public support may be due to the high inherent administrative and/or information costs. Indeed, we agree with Ociepa-Kubicka and Pachura [46] who argue that deficient access to existing subsidies and fiscal incentives are clear barriers to develop eco-innovations. In the same line is the work of Liu and Bay [67], who point out that indirect aid is not effective, as only direct subsidies capable of encouraging eco-innovations. 
Table 3. Descriptive statistics and correlations.

\begin{tabular}{|c|c|c|c|c|c|c|c|c|c|c|c|}
\hline Spanish Companies $(\mathrm{n}=1802)$ & Mean & Standard Deviation & EP & FB & LF & SF & OTF & TD & SIZ & INC & AGE \\
\hline $\mathrm{EP}$ & 0.55 & 0.497 & 1.00 & & & & & & & & \\
\hline FB & 0.44 & 0.496 & $0.049 *$ & 1.00 & & & & & & & \\
\hline LF & 11.53 & 193.723 & $0.124^{* *}$ & 0.002 & 1.00 & & & & & & \\
\hline $\mathrm{SF}$ & 31.51 & 410.282 & 0.150 ** & 0.035 & 0.011 & 1.00 & & & & & \\
\hline OTF & 15.92 & 289.491 & $0.119^{* *}$ & 0.021 & $0.105^{* *}$ & $0.175^{* *}$ & 1.00 & & & & \\
\hline $\mathrm{TD}$ & $49,646.64$ & $410,896.107$ & $0.242 * *$ & 0.050 * & $0.180 * *$ & $0.096^{* *}$ & 0.011 & 1.00 & & & \\
\hline SIZ & 153.16 & 592.542 & 0.391 ** & 0.034 & $0.294^{* *}$ & $0.131 * *$ & $0.528^{* *}$ & $0.534^{* *}$ & 1.00 & & \\
\hline INC & $53,140,267.08$ & $315,201,465.318$ & $0.420 * *$ & 0.017 & 0.359 ** & $0.057 *$ & $0.138 * *$ & $0.569^{* *}$ & $0.698^{* *}$ & 1.00 & \\
\hline AGE & 36.65 & 18.896 & $0.101 * *$ & $0.105^{* *}$ & 0.010 & $0.074^{* *}$ & $0.068 * *$ & $0.142 * *$ & $0.129 * *$ & $0.067 * *$ & 1.00 \\
\hline
\end{tabular}

For each pair of continuous variables, the Pearson coefficient of variation is obtained, in the opposite case that of Spearman ${ }^{*} p<0.05$; ${ }^{* *} p<0.01$. Source: author-compiled data. 
Table 4 shows the frequencies of the dichotomous variables.

Table 4. Frequencies of dichotomous variables.

\begin{tabular}{ccc}
\hline Sample $(\mathbf{n}=\mathbf{1 5 9 4})$ & No & Yes \\
\hline FB & 56.4 & 43.6 \\
EP & 44.6 & 55.4 \\
\hline
\end{tabular}

Source: author-compiled data.

Table 5 shows the results obtained from the regression model.

Table 5. Binary logistic regression results.

\begin{tabular}{|c|c|c|c|}
\hline \multicolumn{2}{|c|}{ Model } & \multirow{2}{*}{$\begin{array}{c}\text { Without Interaction } \\
\text { Values }\end{array}$} & \multirow{2}{*}{$\begin{array}{c}\text { With Interactions } \\
\text { Values }\end{array}$} \\
\hline Variables & Hypotheses & & \\
\hline FB & $\mathrm{H}_{1}$ & 0.226 ** & 0.134 \\
\hline LF & $\mathrm{H}_{2 \mathrm{a}}$ & 0.003 & 0.002 \\
\hline SF & $\mathrm{H}_{2 b}$ & $0.002 *$ & 0.001 \\
\hline OTF & $\mathrm{H}_{2 b}$ & $0.017^{* *}$ & 0.006 \\
\hline $\mathrm{TD}$ & $\mathrm{H}_{2 \mathrm{c}}$ & 0.001 & 0.001 \\
\hline SIZE & - & $0.004^{* * *}$ & $0.004^{* * *}$ \\
\hline INC & - & $0.000 * * *$ & $0.001^{* * *}$ \\
\hline AGE & - & 0.001 & 0.005 \\
\hline $\mathrm{FAM}^{*} \mathrm{LF}$ & $\mathrm{H}_{3 a}$ & & 0.003 \\
\hline $\mathrm{FAM}^{*} \mathrm{SF}$ & $\mathrm{H}_{3 b}$ & & $0.022 * *$ \\
\hline FAM $^{*} \mathrm{OTF}$ & $\mathrm{H}_{3 b}$ & & 0.029 \\
\hline $\mathrm{FAM}^{*} \mathrm{TD}$ & $\mathrm{H}_{3 \mathrm{c}}$ & & $0.001 *$ \\
\hline Const. & - & -0.646 & 0.607 \\
\hline $\mathrm{R}^{2 \text { (Nagelkerke) }}$ & & & 0.208 \\
\hline
\end{tabular}

Finally, in relation to the specific case of $\mathrm{FB}$, again we have not found previous empirical research approaching this issue. In our analysis we find evidence of a positive and significant relationship between FBs receiving state or other public funding and their environmental protection expenses, thus we accept $\mathrm{H}_{3 \mathrm{~b}}$. Moreover, we also find significant evidence on those who receive indirect fiscal support and develop PES; hence we also accept $\mathrm{H}_{3 c}$. These results are in line with the paper by Schäfer et al. [57] but with a opposite sign; as well as with the ideas of Canavati [60] about the need of improving indirect support for FBs to encourage responsibility concerns. However, as in the previous general case, no significant evidence has been found regarding the relationship between FB receiving local public funding and their environmental protection expenses. Consequently, we reject $\mathrm{H}_{3 \mathrm{a}}$. In sum, we agree with Martínez-Alonso et al. [61] and with Dou et al. [23], but with no evidence regarding the local support.

\section{Conclusions}

There has been growing discussion regarding the potential of family firms to embrace practices of corporate sustainability. In view of the literature and given the ambiguity of the results, we have addressed this analysis on the SEW theories, representing one of the widely adopted frameworks in FBs studies on CSR. Our paper, then, was intended to shed light on how family businesses react to environmental responsibility decisions and how these decisions are affected by public policies, as well as financial and fiscal support, given the relevance of FBs in most economies around the world and the gap in literature about the issue. Specifically, we confirm that there are significant differences among family and non-family firms over PES, just as there are differences between family and non-family firms in relation to CSR $[13,14]$, and that there is a positive relationship between state direct 
and indirect funding and FB's environmental concern, but we cannot confirm this relation in the case of local support.

Following our results, we can conclude that the family nature of the firm should be considered as a driver towards environmental commitment, which implies a great capacity for strategic response with today's society, where environmental commitment and a proactive attitude towards the global development goals is key and necessary for our social coexistence. Understanding FBs behavior over these issues is highly relevant, due to their significant influence and their high potential to assist governments and all agents involved, in order to address the environmental challenge that the world is facing today [25]. In short, we agree with Sharma and Sharma [9] on the fact that the vision and long-term commitment of the family business is an aspect that has a direct and positive impact on this type of responsible activity, contributing with this result to the reinforcement of the close identification of the family with the firm as a dimension of SEW theory in a positive sense: those FBs in which the family has enough unrestricted choice to impose its will over non-family shareholders, the company will be open to implement environmentally friendly policies with fewer restrictions, even if these policies turn out to be riskier or not based on economic logic, in order to preserve the socio-emotional endowment [12].

Regarding government aid, our analysis discriminates among direct-indirect, localstate different types of support as a clear academic contribution. In this regard, we conclude that direct support received from central or state public entities, as well as indirect aid via tax deductions or incentives, clearly favors and positively influences a proactive environmental strategic commitment in family firms. However, local financial support has not been proved to provoke this effect.

Following Bansal and Roth [6], to deepen the analysis over the factors influencing firm's environmental commitment is needed for managers and policy makers to determine the relative effectiveness of the different mechanisms and measures implemented to promote sustainability. Our results clearly contribute in this direction for family business managers, when it comes to understand the importance of this type of aid when making their strategic decisions and the need to know all the supports available, given their interest in contributing to improving the well-being of the local community in which they operate. Moreover, these conclusions are also interesting for governments and policymakers, when it comes to decide and drive aids in the right direction, to those companies who really take advantage of the funding received to increase their actions towards a responsible environmental concern.

On this point, it is interesting to highlight the importance of reducing administrative processes and costs for the beneficiaries regarding direct and indirect support; since as Ociepa-Kubicka and Pachura [46] indicate, an inadequate access to existing public support or fiscal incentives may become a barrier. It would be unfortunate, at this stage of the millennium and with the multiple surrounding environmental urgencies, wasting the talent of those who are able to provide in the right direction.

The results in terms of local support are striking for both family and non-family firms, since the relationship is not significant in either case. This conclusion invites us to meditate, and even more so in the case of FBs, which tend to be smaller and deeply rooted in their local communities, as it has been perceived throughout the literature analysis. Therefore, regional and local governments should oversee channeling such aid from higher organizations, such as European or state funds. Today, more than ever, the move towards a more sustainable economy requires the interest to be turned towards local communities, and that their development must be promoted in all aspects. No one better than local administrations to really understand the needs of all the agents involved, correctly direct the support and reduce all possible obstacles to its access.

The main limitations of our paper arise from the sample, which, although representative and reliable, is limited to only one country and one year. However, the relationships that are analyzed along the paper are not considered to change over time and, therefore, we do not think it determinant. It would be interesting to develop the analysis with a greater 
sample, including different economic sectors and countries. As a future study and considering the moment of uncertainty in which we find ourselves because of the pandemic, we think it interesting to deepen the analysis of FBs towards responsibility actions and how they are reacting to face the situation, in terms of human resources, sustainability and profitability. The SEW approach seems to have plenty of room for discussion and is perceived in the literature as an appropriate perspective for advancing the field focusing on the uniqueness of the family firms' identity over the consideration of any other factor.

Author Contributions: Conceptualization, S.B.-H., C.L.-C.-N. and T.P.-B.; methodology, S.B.-H.; software, S.B.-H.; validation, S.B.-H., C.L.-C.-N. and T.P.-B.; formal analysis, S.B.-H., C.L.-C.-N.; investigation, C.L.-C.-N. and T.P.-B.; resources, C.L.-C.-N.; data curation, S.B.-H.; writing-original draft preparation, T.P.-B.; writing-review and editing, S.B.-H., C.L.-C.-N. and T.P.-B.; project administration, S.B.-H., C.L.-C.-N. and T.P.-B.; funding acquisition, S.B.-H. All authors have read and agreed to the published version of the manuscript.

Funding: This research received no external funding.

Institutional Review Board Statement: Not applicable.

Informed Consent Statement: Not applicable.

Data Availability Statement: This study uses information collected from the Survey on Business Strategies (SBS), which is a firm-level panel of data compiled by the Spanish Ministry of Science and Technology. https://fundacionsepi.es/investigacion/esee/en/spresentacion.asp (accessed on 10 October 2021).

Acknowledgments: We would like to acknowledge Universidad Politécnica de Madrid for the support in the development of the paper.

Conflicts of Interest: The authors declare no conflict of interest.

\section{References}

1. European Comission. A Renewed EU Strategy 2011-2014 for CSR. 2011. Available online: https://ec.europa.eu/commission/ presscorner/detail/en/MEMO_11_730 (accessed on 16 November 2021).

2. Torugsa, N.A.; O'Donohue, W.; Hecker, R. Capabilities, proactive CSR and financial performance in SMEs: Empirical evidence from an Australian manufacturing industry sector. J. Bus. Ethics 2012, 109, 483-500. [CrossRef]

3. Cosma, S.; Schwizer, P.M.; Nobile, L.; Leopizzi, R. Environmental attitude on the board. Who are the "green directors"? Evidences from Italy. Bus. Strategy Environ. 2021, 30, 3360-3375. [CrossRef]

4. Sharma, S.; Vredenburg, H. Proactive corporate environmental strategy and the development of competitively valuable organizational capabilities. Strateg. Manag. J. 1998, 19, 729-753. [CrossRef]

5. Hart, S.L. A natural-resource-based view of the firm. Acad. Manag. Rev. 1995, 20, 986-1014.

6. Bansal, P.; Roth, K. Why companies go green: A model of ecological responsiveness. Acad. Manag. J. 2000, 43, 717-736. [CrossRef]

7. Aragón-Correa, J.A.; Sharma, S. A contingent resource-based view of proactive corporate environmental strategy. Acad. Manag. Rev. 2003, 28, 71-88. [CrossRef]

8. Darnall, N.; Henriques, I.; Sadorsky, P. Adopting proactive environmental strategy: The influence of stakeholders and firm size. J. Manag. Stud. 2010, 47, 1072-1094. [CrossRef]

9. Sharma, P.; Sharma, S. Drivers of proactive environmental strategy in family firms. Bus. Ethics Q. 2011, 21, 309-334. [CrossRef]

10. Chrisman, J.J.; Chua, J.H.; Sharma, P. Trends and directions in the development of a strategic management theory of the family firm. Entrep. Theory Pract. 2005, 29, 555-576. [CrossRef]

11. Gómez-Mejía, L.R.; Haynes, K.; Nuñez-Nickel, M.; Jacobson, K.J.L.; Moyano-Fuentes, J. Socioemotional wealth and business risks in family-controlled firms: Evidence from Spanish olive oil mills. Adm. Sci. Q. 2007, 52, 106-137. [CrossRef]

12. Berrone, P.; Cruz, C.; Gomez-Mejia, L.R. Socioemotional wealth in family firms: Theoretical dimensions, assessment approaches, and agenda for future research. Fam. Bus. Rev. 2012, 25, 258-279. [CrossRef]

13. Fitzgerald, M.A.; Haynes, G.W.; Schrank, H.L.; Danes, S.M. Socially responsible processes of small family business owners: Exploratory evidence from the national family business survey. J. Small Bus. Manag. 2010, 48, 524-551. [CrossRef]

14. López-Cózar-Navarro, C.; Priede-Bergamini, T.; Benito-Hernandez, S. The Link between Firm Size and Corporate Social Responsibility. Ethical Perspect. 2017, 24, 259-296. [CrossRef]

15. Block, J.H.; Wagner, M. The effect of family ownership on different dimensions of corporate social responsibility: Evidence from large US firms. Bus. Strategy Environ. 2014, 23, 475-492. [CrossRef]

16. Marques, P.; Presas, P.; Simon, A. The heterogeneity of family firms in CSR engagement: The role of values. Fam. Bus. Rev. 2014, 27, 206-227. [CrossRef] 
17. Hilliard, I.; Priede, T. Benchmarking responsible management and non-financial reporting. Benchmarking Int. J. 2018, 25, 2931-2949. [CrossRef]

18. Craig, J.; Dibrell, C. The natural environment, innovation, and firm performance: A comparative study. Fam. Bus. Rev. 2006, 19, 275-288. [CrossRef]

19. Berrone, P.; Cruz, C.; Gómez-Mejía, L.R.; Larraza-Kintana, M. Socioemotional wealth and corporate responses to institutional pressures: Do family-controlled firms pollute less? Adm. Sci. Q. 2010, 55, 82-113. [CrossRef]

20. Dekker, J.; Hasso, T. Environmental Performance Focus in Private Family Firms: The Role of Social Embeddedness. J. Bus. Ethics 2016, 136, 293-309. [CrossRef]

21. Doluca, H.; Wagner, M.; Block, J. Sustainability and environmental behaviour in family firms: A longitudinal analysis of environment-related activities, innovation and performance. Bus. Strategy Environ. 2018, 27, 152-172. [CrossRef]

22. Dangelico, R.M.; Nastasi, A.; Pisa, S. A comparison of family and nonfamily small firms in their approach to green innovation: A study of Italian companies in the agri-food industry. Bus. Strategy Environ. 2019, 28, 1434-1448. [CrossRef]

23. Dou, J.; Su, E.; Wang, S. When Does Family Ownership Promote Proactive Environmental Strategy? The Role of the Firm's Long-Term Orientation. J. Bus. Ethics 2019, 158, 81-95. [CrossRef]

24. United Nations. Bruthland Report. New York. Available online: http://www.ecominga.uqam.ca/PDF/BIBLIOGRAPHIE/ GUIDE_LECTURE_1/CMMAD-Informe-Comision-Brundtland-sobre-Medio-Ambiente-Desarrollo.pdf (accessed on 16 November 2021).

25. Van Gils, A.; Dibrell, C.; Neubaum, D.O.; Craig, J.B. Social issues in the family enterprise. Fam. Bus. Rev. 2014, 27, 193-205. [CrossRef]

26. Samara, G.; Jamali, D.; Sierra, V.; Parada, M.J. Who are the best performers? The environmental social performance of family firms. J. Fam. Bus. Strategy 2018, 9, 33-43. [CrossRef]

27. Van Marrewijk, M.; Werre, M. Multiple levels of corporate sustainability. J. Bus. Ethics 2003, 44, 107-119. [CrossRef]

28. Du, S.; Swaen, V.; Lindgreen, A.; Sen, S. The roles of leadership styles in corporate social responsibility. J. Bus. Ethics 2013, 114, 155-169. [CrossRef]

29. Tagiuri, R.; Davis, J.A. On the goals of successful family companies. Fam. Bus. Rev. 1992, 5, 43-62. [CrossRef]

30. Churchill, N.C.; Hatten, K.J. Non-market-based transfers of wealth and power: A research framework for family businesses. Am. J. Small Bus. 1987, 11, 51-64. [CrossRef]

31. Zellweger, T.M.; Eddleston, K.A.; Kellermanns, F.W. Exploring the concept of familiness: Introducing family firm identity. J. Fam. Bus. Strategy 2010, 1, 54-63. [CrossRef]

32. Mazzelli, A.; Kotlar, J.; De Massis, A. Blending in while standing out: Selective conformity and new product introduction in family firms. Entrep. Theory Pract. 2018, 42, 206-230. [CrossRef]

33. López-Pérez, M.E.; Melero-Polo, I.; Vázquez-Carrasco, R.; Cambra-Fierro, J. Sustainability and business outcomes in the context of SMEs: Comparing family firms vs. non-family firms. Sustainability 2018, 10, 4080. [CrossRef]

34. Kuttner, M.; Feldbauer-Durstmüller, B.; Mitter, C. Corporate social responsibility in Austrian family firms: Socioemotional wealth and stewardship insights from a qualitative approach. J. Fam. Bus. Manag. 2021, 11, 238-253. [CrossRef]

35. Venturelli, A.; Principale, S.; Ligorio, L.; Cosma, S. Walking the talk in family firms. An empirical investigation of CSR communication and practices. Corp. Soc. Responsib. Environ. Manag. 2021, 28, 497-510. [CrossRef]

36. Curado, C.; Mota, A. A Systematic Literature Review on Sustainability in Family Firms. Sustainability 2021, 13, 3824. [CrossRef]

37. Cruz, C.; Larraza-Kintana, M.; Garcés-Galdeano, L.; Berrone, P. Are family firms really more socially responsible? Entrep. Theory Pract. 2014, 38, 1295-1316. [CrossRef]

38. Campopiano, G.; De Massis, A. Corporate social responsibility reporting: A content analysis in family and non-family firms. $J$. Bus. Ethics 2015, 129, 511-534. [CrossRef]

39. Le Breton-Miller, I.; Miller, D. Family firms and practices of sustainability: A contingency view. J. Fam. Bus. Strategy 2016, 7, 26-33. [CrossRef]

40. Huang, Y.C.; Yang, M.L.; Wong, Y.J. The effect of internal factors and family influence on firms' adoption of green product innovation. Manag. Res. Rev. 2016, 39, 1167-1198. [CrossRef]

41. Memili, E.; Fang, H.C.; Koc, B.; Yildirim-Oktem, O.; Sonmez, S. Sustainability practices of family firms: The interplay between family ownership and long-term orientation. J. Sustain. Tour. 2018, 26, 9-28. [CrossRef]

42. Bansal, P. Evolving sustainably: A longitudinal study of corporate sustainable development. Strateg. Manag. J. 2005, 26, 197-218. [CrossRef]

43. Pedersen, E.R. The many and the few: Rounding up the SMEs that manage CSR in the supply chain. Supply Chain Manag. 2009, 14, 109-116. [CrossRef]

44. Ghisetti, C.; Mancinelli, S.; Mazzanti, M.; Zoli, M. Financial barriers and environmental innovations: Evidence from EU manufacturing firms. Clim. Policy 2017, 17, S131-S147. [CrossRef]

45. Triguero, Á.; Cuerva, M.C.; Álvarez-Aledo, C. Environmental innovation and employment: Drivers and synergies. Sustainability 2017, 9, 2057. [CrossRef]

46. Ociepa-Kubicka, A.; Pachura, P. Eco-innovations in the functioning of companies. Environ. Res. 2017, 156, 284-290. [CrossRef] [PubMed] 
47. Scarpellini, S.; Marín-Vinuesa, L.M.; Portillo-Tarragona, P.; Moneva, J.M. Defining and measuring different dimensions of financial resources for business eco-innovation and the influence of the firms' capabilities. J. Clean. Prod. 2018, 204, 258-269. [CrossRef]

48. Horbach, J. Determinants of environmental innovation-New evidence from German panel data sources. Res. Policy 2008, 37, 163-173. [CrossRef]

49. De Marchi, V. Environmental innovation and R\&D cooperation: Empirical evidence from Spanish manufacturing firms. Res. Policy 2012, 41, 614-623. [CrossRef]

50. Hoogendoorn, B.; Guerra, D.; van der Zwan, P. What drives environmental practices of SMEs? Small Bus. Econ. 2015, 44, 759-781. [CrossRef]

51. Cecere, G.; Corrocher, N.; Mancusi, M.L. Financial constraints and public funding of eco-innovation: Empirical evidence from European SMEs. Small Bus. Econ. 2020, 54, 285-302. [CrossRef]

52. Blanes, J.V.; Busom, I. Who participates in R\&D subsidy programs? The case of Spanish Manufacturing firms. Res. Policy 2004, 33, 1459-1476. [CrossRef]

53. Mazzanti, M.; Zoboli, R. The drivers of environmental innovation in local manufacturing systems. Econ. Politica 2005, 22, 399-438. [CrossRef]

54. Bingham, J.B.; Dyer, W.G.; Smith, I.; Adams, G.L. A stakeholder identity orientation approach to corporate social performance in family firms. J. Bus. Ethics 2011, 99, 565-585. [CrossRef]

55. López-González, E.; Martínez-Ferrero, J.; García-Meca, E. Corporate social responsibility in family firms: A contingency approach. J. Clean. Prod. 2019, 211, 1044-1064. [CrossRef]

56. Lopez-Fernandez, M.C.; Serrano-Bedia, A.M.; Gómez-López, R. Determinants of innovation decision in small and medium-sized family enterprises. J. Small Bus. Enterp. Dev. 2016, 23, 408-427. [CrossRef]

57. Schäfer, D.; Stephan, A.; Mosquera, J.S. Family ownership: Does it matter for funding and success of corporate innovations? Small Bus. Econ. 2017, 48, 931-951. [CrossRef]

58. Carney, M.; Zhao, J.; Zhu, L. Lean innovation: Family firm succession and patenting strategy in a dynamic institutional landscape. J. Fam. Bus. Strategy 2019, 10, 100247. [CrossRef]

59. Manzaneque, M.; Rojo-Ramírez, A.A.; Diéguez-Soto, J.; Martínez-Romero, M.J. How negative aspiration performance gaps affect innovation efficiency. Small Bus. Econ. 2018, 54, 209-233. [CrossRef]

60. Canavati, S. Corporate social performance in family firms: A meta-analysis. J. Fam. Bus. Manag. 2018, 8, 235-273. [CrossRef]

61. Martínez-Alonso, R.; Martínez-Romero, M.J.; Rojo-Ramírez, A.A. Examining the Impact of Innovation Forms on Sustainable Economic Performance: The Influence of Family Management. Sustainability 2019, 11, 6132. [CrossRef]

62. Fariñas, J.C.; Jaumandreu, J. Diez años de encuesta sobre estrategias empresariales (ESEE). Econ. Ind. 1999, 329, $29-42$.

63. Cavaco, S.; Crifo, P. CSR and financial performance: Complementarity between environmental, social and business behaviors. Appl. Econ. 2014, 46, 3323-3338. [CrossRef]

64. Earnhart, D. The effect of corporate environmental performance on corporate financial performance. Annu. Rev. Resour. Econ. 2018, 10, 425-444. [CrossRef]

65. Yáñez-Araque, B.; Hernández, J.P.S.-I.; Gutiérrez-Broncano, S.; Jiménez-Estévez, P. Corporate social responsibility in micro-, small-and medium-sized enterprises: Multigroup analysis of family vs. nonfamily firms. J. Bus. Res. 2021, 124, 581-592. [CrossRef]

66. Neubaum, D.O.; Dibrell, C.; Craig, J.B. Balancing natural environmental concerns of internal and external stakeholders in family and non-family businesses. J. Fam. Bus. Strategy 2012, 3, 28-37. [CrossRef]

67. Liu, W.; Bai, Y. An Analysis on the Influence of R\&D Fiscal and Tax Subsidies on Regional Innovation Efficiency: Empirical Evidence from China. Sustainability. 2021, 13, 12707. [CrossRef] 